\title{
A Comparative study of product life cycle and its marketing applications
}

\author{
${ }^{1}$ Ram Komal Prasad, ${ }^{2}$ Manoj K. Jha and ${ }^{3}$ Sanjeev Verma \\ ${ }^{1}$ Doctoral Fellow of NITIE Mumbai and Assistant Professor, ICCMRT, Lucknow, India \\ ${ }^{2}$ Associate Professor, National Institute of Industrial Engineering (NITIE), Mumbai, India \\ ${ }^{3}$ Professor, National Institute of Industrial Engineering (NITIE), Mumbai, India
}

\begin{abstract}
In this paper we explain the product life-cycle models that studies a set of strategic choices facing manufacturers as they design the product/service bundle which may require maintenance and repair support after its sale. Traditional market analysis relies on purely macroeconomic and political factors and fails to account for an emerging market's dynamism and future potential. The objective of this paper is to present all composed product life cycle (PLC) specific to the assessment of emerging markets at domestic and international expansion opportunities. Based on the literature pointing out the product life cycle in domestic and international markets with graphic presentation and models the need for a specialized composite and comprehensive approach, additional criteria are introduced to assess emerging market potential. Emerging markets provided the rationale for the product life cycle in dealing with common product life cycle (FMCG), retail PLC, industrial products PLC, services PLC, engineering PLC and international PLC criteria. Marketing with PLC philosophy gives insights to practicing managers to follow the options and make visionary decisions for products they are dealing with. Composite PLC has been overlooked in literature and this paper will fill the gaps by collective study on five market conditions.
\end{abstract}

Keywords: product life-cycle, marketing

DOI: $10.7176 / \mathrm{JMCR} / 63-06$

Publication date: December $31^{\text {st }} 2019$

\section{Introduction:}

A product is believed to go through definite life stages in the same manner as a living organism. Products are first introduced in the market and customers accept if they find it serving their needs, sales go rapidly. Finally, everyone who needs the product acquires it and sales plateau. At some stage, either the need for product was satisfying to see to exists, or a different solution to that need emerges. A customer stops buying the product and eventually the product sees to exists. A company which introduces new product naturally hopes that the product will contribute to the product and provide consumers satisfaction for a long period of time. This, however, does not happen in practice so progressive organization tries to remain aware of what is happing throughout the life of the product in terms of sales and resultant profit. Theodore Levitt (1965), A well-known marketing management thinker has produced his ideas in the basic concept of the life cycle of the product

\section{Concept of Product life cycle:}

Levitt idealize the concept of the product life cycle as-

1. Products have a limited life span

2. The sales and consumptions passed through distinct stages, each poses different challenges, opportunities, and problems to the sellers.

3. Profit rise and falls at different stages of the life cycle of products.

4. Product required different marketing financial, manufacturing, purchasing and human resource strategy in each stage of their life cycle.

The product life curves are portrait and bell/saved and it is divided into four stages.

1. Introductory Stage- There is likely to be no profit is more likely to lose at the entry stage of any product. This loss may continue for some time depending on market factors. Thus, there may be either lost in the begging throughout or either profit rise rapidly or gradually. At this stage, a considerable amount of funds are being 
revolted to promotional schemes with a view to generating sales while the volume sales are low. Thus, in the beginning, there is likely to be lost and later on, as sales grow, the profit might accumulate.

2. Growth stage- In the case of a product launched successful, the sales stars picking or rise more rapidly. The next stage is reached which is known as the growth stage. Here the sale would climb up fast and profit picture will also be improved considerably. This is because the cost of distribution and promotion is now spread over larger volume of sales. As the volume of production is increased, the manufacturing cost per unit tends to decline. Thus, from a strategic point of view, this is a very critical stage.

3. Maturity stage- It is too optimistic to think that the sale will keep shooting up. At this stage, it is more likely that the competitors become more active. If the product is a novel one, by now completion would have come out with similar products in the market to compete with. Therefore the sales are likely pushed to downwards by competitors by professional efforts would have to increase to try and sustained to sales. This is called the maturate stage. At this point, it is difficult to push up sales. With regard to the profit picture, the profit is likely to be stabilized or start declining, and more promotional efforts have to be taken now in order to meet the competition.

The 4 Life Cycle Stages and their Marketing Implications

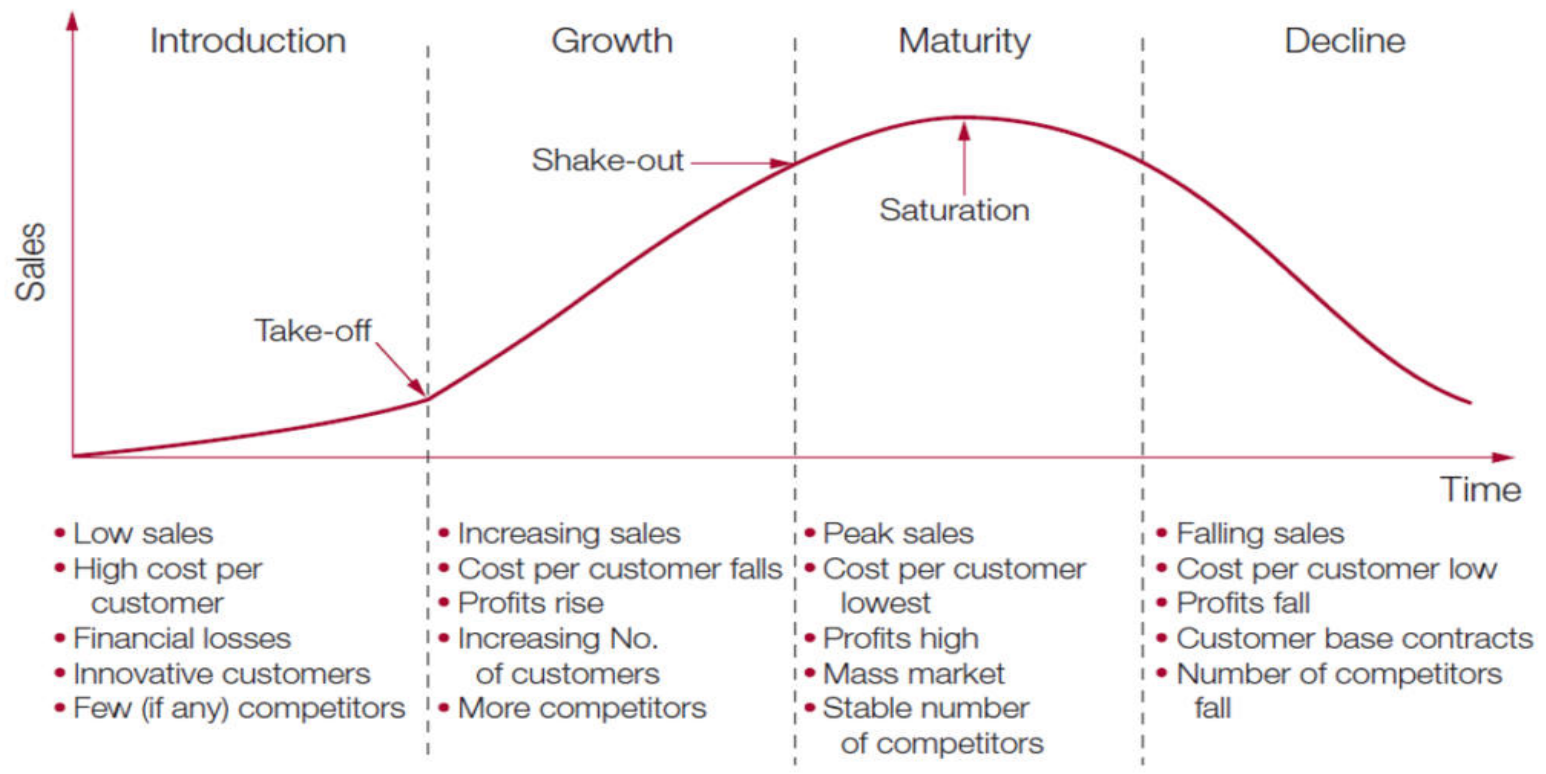

Figure-1: Product Life Cycle (PLC) Stageses

4. The decline or obsolence stage- there after sales are likely to decline and the product could reach to obsolete stage. Steps are to be taken to prevent obsolete and avoid their decline. This decline that generally follows could be due to reseeds such that consumers changes in taste and preferences, improvement in technology or introduction of better substitute. This is the stage where the profit drops rapidly and ultimately the last stage emerges. Retaining such a profit after these stages may be risky and certainly not profitable to the organization.

This concept of product life cycle is applicable to all consumer product, durables and non durables.

Product Life cycle of industrial products- Although Product Life Cycle (PLC) analysis has received limited attention in developing industrial marketing strategy; it is a very useful concept to the marketers of industrial products. John Smallwood ( ) points out 'The maturation of product technology and product configuration along with marketing program proceeds in order, somewhat the predictable course between over time with the merchandising nature and marketing environment noticeable similarities between the product that is in the same stage of their lifecycle. It is used as a concept in forecasting, pricing, advertising, product planning and another aspect of marketing management can make it a valuable concept, although a considerable amount of judgment must be used in its application. PLC analysis enables marketers to determine where the product is in its lifecycle to develop appropriate strategies aimed at those covering the application. 
1. Introduction Stages- Product acceptances during the introductory stage of industrial products, is considerably different from what a generally experienced in the consumer market. While some products are rapidly accepted, others are accepted very slow and entirely considerable market development before reaching and appreciable growth stage. Product acceptance in the industrial market is affected by how the product fits into the buyer's total used system. Generally, the use system involves other products, other people, and habitual skills. When the product has a potential for rapid acceptance, the marketer must be prepared to meet rigors completion but with slow acceptance, marketing strategy focus on market development.

2. Growth stage- As the product begins to enter the rapid growth stage, the emphasis on product strategy shifts to improving product design, improving distribution services and lowering price as increasing product demand, accompanied by accumulated product experience, begins to lower cast substantially. As market demand increases, product design and other aspects as the product offering must be changed to both lowed and premium market segments. Further, when availability is weak, competitors are encouraged to enter the market.

3. Maturity Stage- By the time market demand reaches the maturity stage, industrial Byers has found suppliers offering to satisfy their need fairly well and are 'neither reaching for new supplier nor paying much attention to the promotion of another offering'. Marketing strategy, therefore, should be directed to us keeping current user satisfied and looking for the opportunities To find new buyers or enter new markets thorough products modification and change in other marketing mix variables.

4. Decline Stage- Change in customer desire as well as changes in the state of the art that creates better substitute eventually bring about a decline in the sales and profit of every product. When a product enters into decline stage the marketer is faced with choice of phasing the product out is in barking on milking strategy in which marketing expect are sharply reduced to increase profit margin.

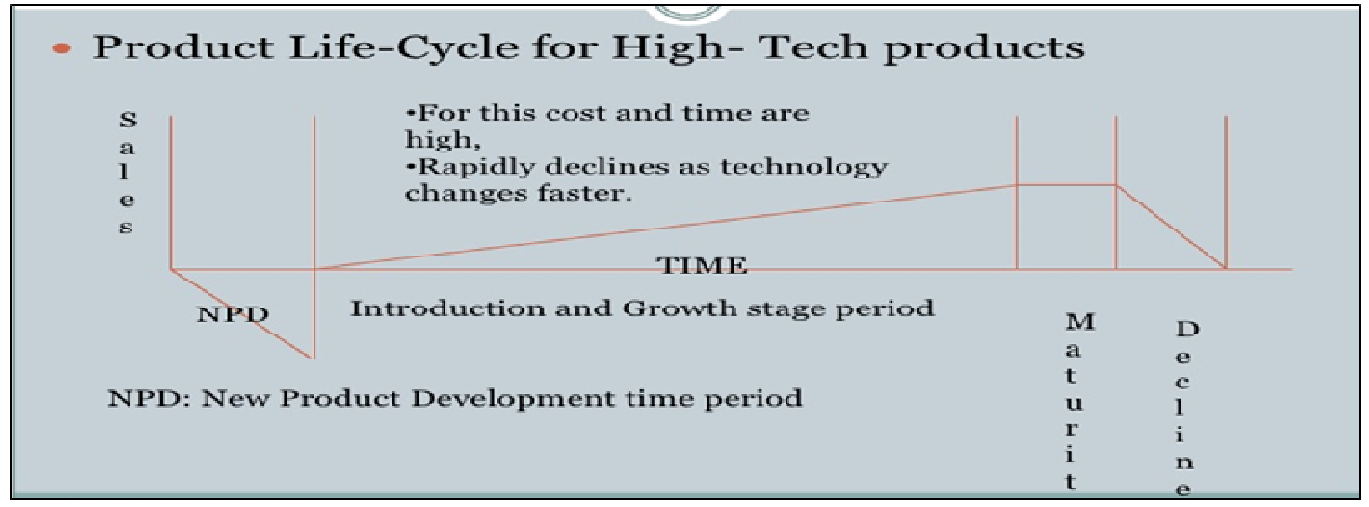

Figure-1: Product Life Cycle (PLC) of industrial products

Service life cycle- Just like the product life cycle, services to have a life cycle if we make a distinction between the service category and the technology change, we can see that many broad service categories are needs remains constant over a long period of time. The technology has altered the products in many cases the basic needs category remaining the same. Technology has now the greatest sophisticated in the mode of delivery has placed many services companies to an augmented bundle of utilities. Theoretically, it can sit that services go through a life cycle similar to products. The individual services companies and services brands still benefit from an analysis of their past and prediction about the future growth potential in a traditional format of life cycle curve. Other stages of the life cycle are-

- $\quad$ Pre-introduction stage- At this stage concept testing can indicate the acceptability of a new services concept. More details test can sure if there is large market to sustain the services over an extended period of time. Specialized technique such as conjoined could be used to identify the attributes which are considered as important by customers, relative to another attribute on offer. 
- $\quad$ Service design- Service design is a major issue apart from the viability of the proposed service, that testing at this stage. Regardless of techniques used to do study, it is necessary to do it to reduce the risk of getting into and unlivable business, or that of entering with a wrong design. It may be pertinent to know that for many services, location with the critical design which can may or break the business.

- $\quad$ Post-launch Stage- There are many things a service provider may want to know from the customers even after he has launched a new service. Particularly, he may want input attribute which customer is happy about those which creating dissatisfaction. They are still hoping that the deficiencies could be ignored out if their existence. This could be done infirmly depending on the nature of the services and efficacy of collecting accurate feedback.

- $\quad$ Retail life cycle-The concept of the product life cycle has been developed by Theodore Levitt and explain properly by Philip Kotler is all applicable to the retail organization because it also passes through identifiable stages of innovation, development, maturity, and decline. The theory of retail lifecycle is about changes through the time of retailing of outlets, It claimed that retail institutions have shown shape through economic life. The S-shaped curve has been classified into four main phases.

- Innovations- A new organization is born, it improves upon the convenience offered or create other advantages to final customers that differ sharply from those offered by retailers. This is the stage of innovations where an organization has few competitors. Since it is a new concept the rate of growth is fairly rapid and the management fine-tunes its strategy through experimentation. The level of profitability is moderate and this can last up to five years that varies from organization to organization.

- Accelerated Growth- The retail organization faces a rapid increase in sales. As the organization moves to stages two of the growth which is the stage of development a few competitions emerge. Since the company has been in the market for a while, it is now opposition to pre-empt the market by establishing opposition to leadership. Since growth is imperative, the investment level is also high, as is the profitability. Investment is largely in system and process. This stage can large from 5 to 10 years, however towards to end there may be heavy cost pressure.

- Maturity- The organization still grows but competitive pressure is acute from newer firms of retailing that intend to arise and therefore growth tends to decrease. Gradually, as a marketer became more competitive and direct competition will increase. The rate of growth slows downing and profit also starts to decline. This is the time when the retail organization needs to rethink its strategy and reposition itself in the market. The change magic place in the format of business as well as merchandise mix.

- Decline-The retail organization loses its competitive edge and its decline. In this stage, the organization needs to decide if it is still going to continue in the markets. If the growth rate is negative, profitability decline further and overheads are very high. 


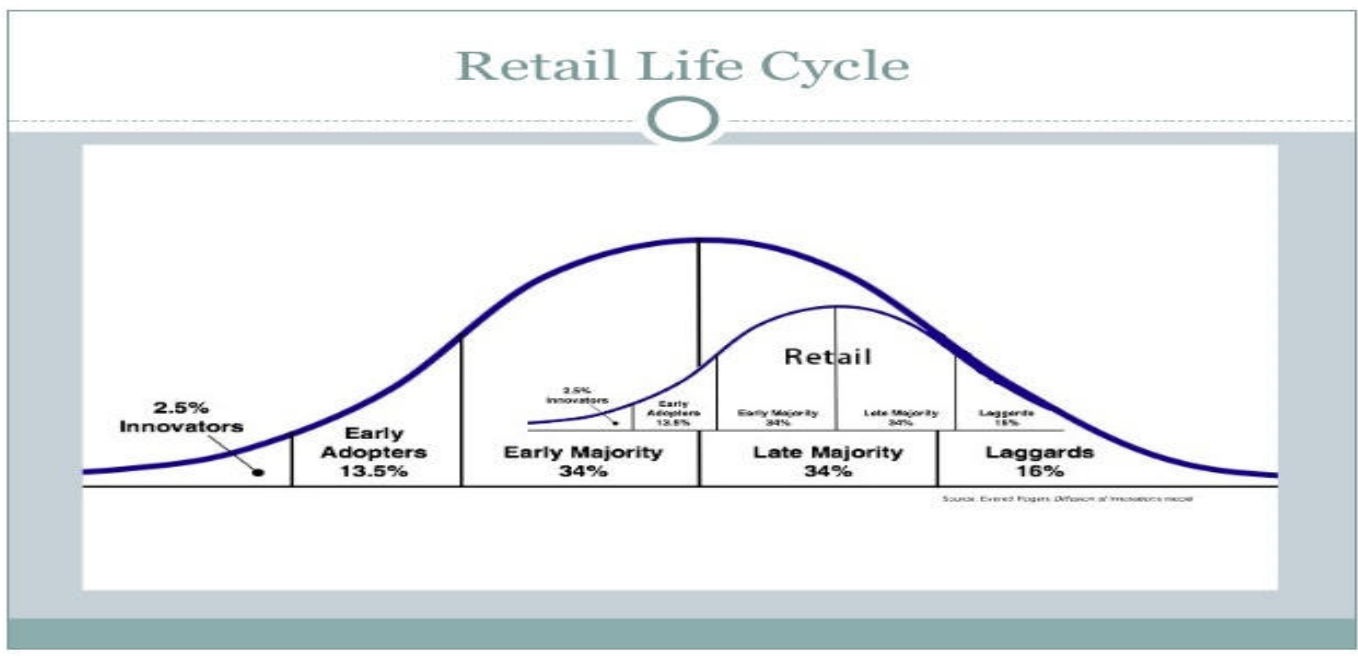

\section{Engineering Product Life Cycle}

Levitt's (1965) description of the market product life cycle strayed outside of the contemporaneous marketing purview; so much so, in fact, that an explicitly non-marketing focus became important if the concept was to retain its relevance. Current product offerings were not the simple output of an individual organization-with traditionally delineated phases of 'life', such as introduction, growth, maturity and decline, as in the traditional PLC model; rather the validity of this a model was being reconsidered in the light of the operation of today's companies, with the subsequent emergence of criticism of the PLC's non-promotion of inter-connections between the phases involved, and its view of the product as having only a relatively finite existence. Contemporary research was to move beyond the one-of-a-kind product life cycle model with isolated phases of introduction, growth, maturity, and decline, as mentioned previously; instead the model was to take into account, in a more explicit manner, the value chain itself, and be in some way part of its own regeneration.

The Engineering-PLC model involves the study of the complete life of a product-from cradle to grave, from product conception, through design, production, sale, customer use, and service, to decommissioning. Currently there is no standardized E-PLC model available-a consequence of researchers in particular research fields investigating PLC elements in relative isolation from each other; however, a number of E-PLC perspectives have been proposed in the last three decades, with one of the most fundamental elements of these models being the consistent reliance upon the same leading publications. Design, Production, Customer Usage and End-of-life decommissioning are common phases in the E-PLC models suggested by these authors. From the point of view of product design, a six-phase life cycle (needs recognition, design/development, production, distribution, usage, and disposal/recycling) is suggested by Alting (1993), who believes that all six phases which a product goes through have to be considered at the conceptual stage. 


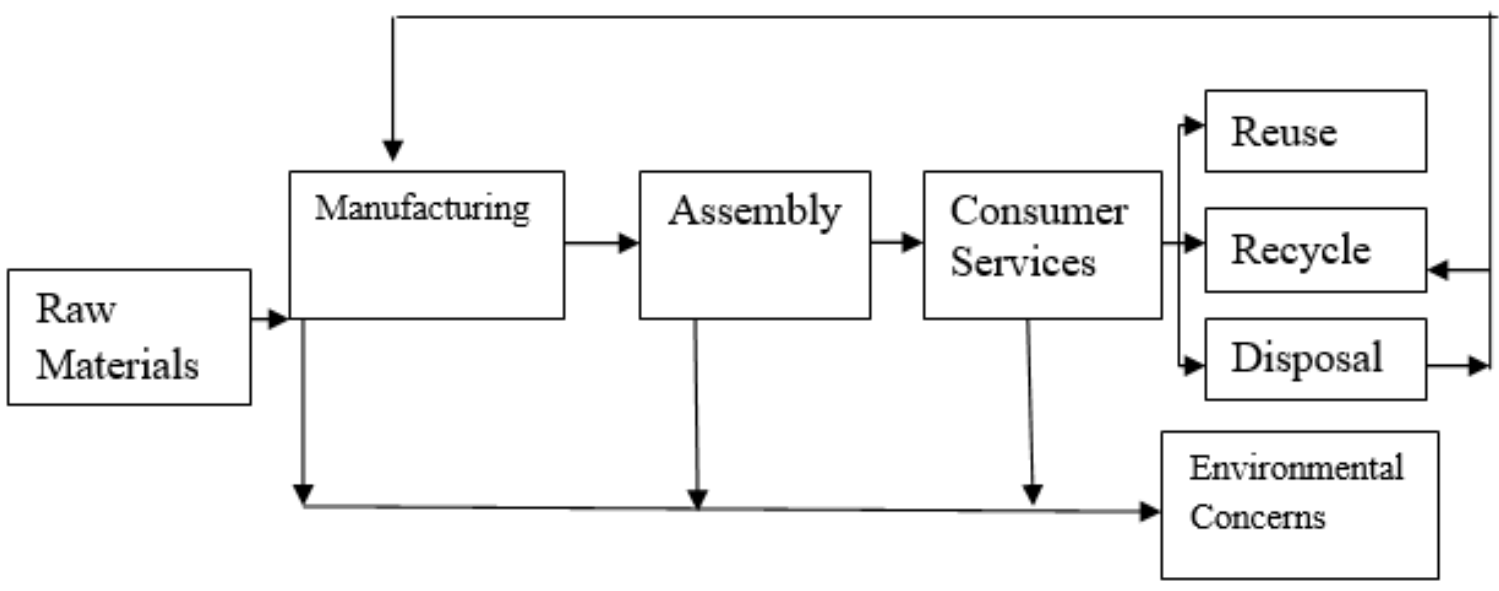

International Product life cycle- Vernon (1966) propounded International product life cycle which discusses the consumption pattern of product in many countries. This concept explains that products pass through several stages of the product life cycle. The products are invocated in the country usually a developed country to satisfy the needs of the consumers. The innovator country wants to exploit the technology breakthrough and start marketing the products in a foreign country. Gradually, the foreign country also starts production and becomes efficient in producing those commodities. As a result, the innovator country becomes the importer of that product advantageous. In this way, the innovator countries become the importer of the products. Terpstra and Strathy ( ) have identified four phases in the international product life cycle.

1. Export strength by Innovator Country-Products are normally innovated in the developed countries because they process the resources to do so. The firms have the technological know-how and sufficient capital to invest in the research and development activities. The need for adoption and modification also forces the production activity to be located near the market to respond quickly towards the change. The customer is affluent in a developed country and prefers to buy new products. Thus the manufacturers are attracted to produce the goods in the developed country and marketed in the home country. After meeting the demand of the home country, the manufacturers start exploring the foreign market and exporting goods to them. This phase exhibits the introduction and growth stage of the life cycle.

2. Foreign Production- The importing firm in the middle-income country realizes the demand potential of the product on the home market. The manufacturer also becomes familiar with producing goods. The growing demand for the product attracts the attention of many firms. They are tempted to start production in their country and gradually start exporting to the low income country. The large production in the middle country reduces the export from the innovating country. This shows the maturity stage of product life cycle where the production activities starts shifting from innovating country to other countries.

3. Foreign production become competitive in export markets- The firms in low income country also rallies the demand potential in the domestic market. They starts product in the home country and exploiting in cheap labor. They gain exporting in manufacturing in commodity. They become more efficient in producing the goods due to low cost of production. Gradually, They starts exporting to goods to other countries the exports firms of country replace the export the innovating country Whose export has already decline. This exhibits the declining stages of product life cycle. This indicates the products gets widely disseminated and other country imitating product. This is third phase of IPLC where the product starts becoming standardize.

4. Import competition starts- The producers in the low income importing country gain sufficient experience in producing and marketing the products. They attain the economy of scale and gradually become more efficient than innoting country. At this stage innovator country finds the import from this country advantageous. Hence, the innovator country finally become importer of products. In this fourth stage of IPLC the product becomes completely standardized. 


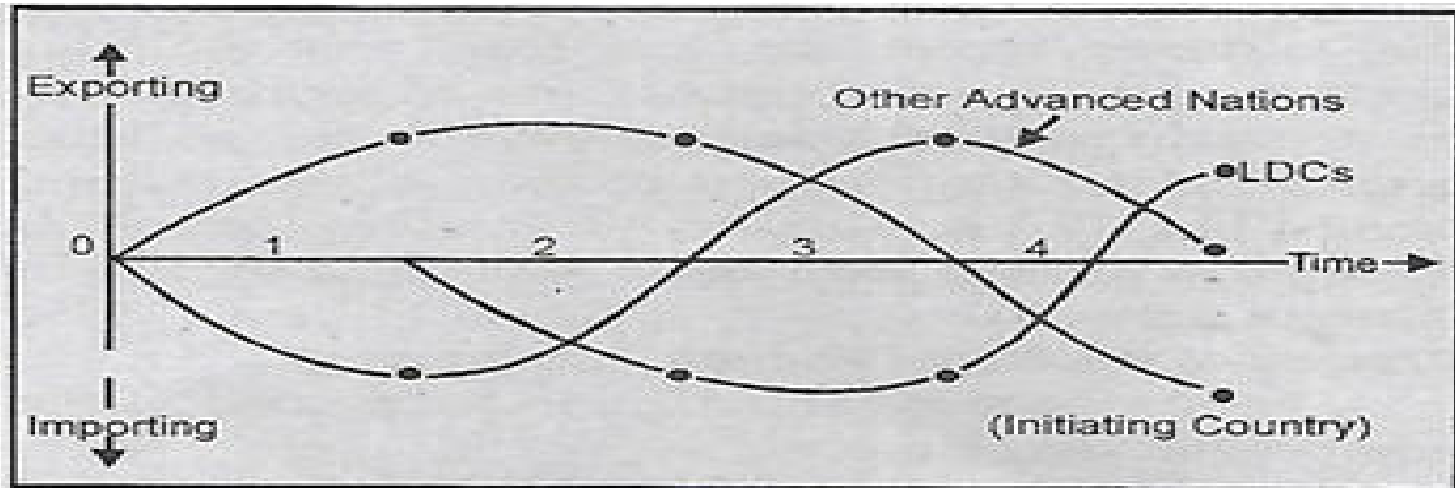

The theory of IPLC brings out that advanced country plays an innovative role in new product development. Later for reasons of comparative advantage or factor endowment and cost, such a product moves over to other developed countries or middle-income countries and ultimately gets produced and exported by less developed countries. A country like Taiwan, Hong Kong, Korea, Singapore, and even India have emerged as major exporter of a growing range of products to the USA, Europe in the decades.

Market Applications: The concepts life cycle can be made applicable to all types of products. It is quite likely that items which are considered necessities such as raw material, food grains, vegetables, fruits etc, do not meet with their death within a short period. However, it must be remembered that over the long term, technological advancement may dispense with a requirement of certain types of raw material as iron ore, whose finished product is steel, and jute facing severe competition from plastic, copper wire used in telecommunication facing severe competition optic fiber and cell phone completely doing away cable. We need to understand that the difference among the products is in the terms of length of life but the basic fact is that all tings born has to die one day.

The ultimate purpose of the product life cycle model is to act as a broad guide for marketing strategy and planning. Advances are offered by the new concept in two important areas. The first is an improved basis to both define the current product life cycle phase and forecast future transitions. The second is to provide enriched information on consumer trends upon which to base marketing strategy.

During the stage of introduction a new or modified product in the market that targeted segment is not familiar with the product and sales turnover is not likely to be high. In this stage, those customers who normally tend to the experiment with new products are expected to purchase the products. Besides, the company may have to spend substantial amount on promotion and hence, profit are likely to be minimal and in some case negative too. If the product does not die an immediate death and find acceptance among the customers, word spread, sales starts growing and since it means less per unit production, promotion and other cost, profit starts growing. The maturity / saturation stage is chacterised by reduction in unit price and rise in expenditure on promotion to maintain the sales level and hence drop the profit. In the final stage, unless attempts made to stretch the life cycle meet with success, sales starts declining and competing brands gradually starts replacing the company's brand to the withdrawal of the product from the market.

\section{Reference:}

Alting, L. (1993). Life-cycle design of products: a new opportunity for manufacturing enterprises. In A. Kusiak (Ed.), Concurrent Engineering: Automation, Tools, and Techniques (pp. 1-17). New York: Wiley

Aurich, J. C., Fuchs, C., \& DeVries, M. F. (2004). An approach to life cycle oriented technical service design. CIRP Annals, 53(1), 151-154. 
Aurich, J. C., Fuchs, C., \& Wagenknecht, C. (2006). Life cycle oriented design of technical Product-Service Systems. Journal of Cleaner Production, 14(17), 1480-1494.

Ayal, I. (1981). International product life cycle: a reassessment and product policy implications. Journal of Marketing, 45(4), 91-96.

Cateora, P. R. (2007). International Marketing 13E (Sie). Tata McGraw-Hill Education.

Davidson, W. R., Bates, A. D., \& Bass, S. J. (2002). The retail life cycle. Retailing: The evolution and development of retailing, 55(6), 89-96.

Kotler, Philip, Gary Armstrong, L. C. Harris, and N. Piercy. "Principles of Marketing. 6th European edition." Essex: Pearson Education Limited (2013).

Levitt, T. (1965). EXPLOIT the Product Life Cycle. Harvard Business Review, 43(6), 81-94.

Palmer, M. (2005). Crossing Threshold Periods in the Retail Life Cycle:: Insights from Wal-Mart International. European Management Journal, 23(6), 717-729.

Vernon, A. (2005). Multiple oppression and the disabled people's movement. In Understanding Care, Welfare and Community (pp. 82-86). Routledge.

Vernon, R. (1966). International investment and international trade in the product cycle. Quarterly Journal of Economics, 80(2), 190-207

Weber, C. L., Hendrickson, C. T., Matthews, H. S., Nagengast, A., Nealer, R., \& Jaramillo, P. (2009, May). Life cycle comparison of traditional retail and e-commerce logistics for electronic products: A case study of buy. com. In 2009 IEEE International Symposium on Sustainable Systems and Technology (pp. 1-6). IEEE. 